\title{
INTRODUCTION
}

The purpose of this field guide is to identify by full descriptions and illustrations all the native and naturalized trees of central Texas. The very nature of a field guide, however, limits the amount of material it can contain and still be easily carried and used in the field. Because of this limitation, detailed data on the varieties, horticultural forms, propagation, and medicinal uses of the trees have been omitted. The reader who seeks a more in-depth discussion is referred to the author's Trees, Shrubs, and Woody Vines of the Southwest, upon which this guide is based.

Central Texas, roughly the area of the Edwards Plateau, is bordered by the Balcones Escarpment on the south and east, the Pecos River on the west, and the Texas Plains and the Llano Uplift to the north.

\section{What Is a Tree?}

A native tree is one that grows without cultivation. A naturalized tree is one that is introduced from other regions, but one that escapes cultivation and grows freely. A somewhat general definition of a tree has been suggested by some authorities but is not accepted by all. The definition often given is that a tree is a plant with a single woody trunk at least four inches in diameter four feet above the ground, with a definite branched crown, and with a height not less than twelve feet.

This rule may have some exceptions because some trees may have several trunks growing from the base, and some are tall enough but fail to attain the stipulated trunk diameter. Also, some shrubs are treelike but have a number of stems rising from the base. Under unfavorable conditions of soil or climate a true tree may become shrublike, or in favorable circumstances a shrub may become treelike. Also, some species are fast growing and reach maximum 
tree size much quicker than other species. Individual trees vary in size within the same species.

\section{Conservation Importance}

Many organizations have contributed to the overall landuse program of soil conservation: federal bureaus, state agencies, district and county governments, timber producers, processors, and wood products manufacturers. The Texas Parks and Wildlife Department has coordinated the wildlife and park management. It should certainly be fully recognized that trees are of great value for purposes other than providing wood products. Humans, animals, and birds eat the seeds, fruit, and sap. Trees furnish drugs, dyes, and resins, prevent erosion, are good sound barriers, reinstitute the oxygen in the air, and are much used for street, park, and home beautification, for shade, and for shelter-belt planting. All these uses are justifiable reasons for forest conservation and for the protection of all woody species.

\section{Central Texas Tree Zone Defined}

For the purposes of this publication the central Texas tree zone is that section called the Edwards Plateau (see section $\mathrm{H}$ on map 1 ).

Central Texas is often called the Edwards Plateau because of Edwards limestone outcrops above ground or somewhat below the surface. Many millions of years ago marine organisms formed a thick limey ooze on the sea bottom, which was uplifted to form the present-day limestone. It forms a somewhat flattened plateau, cut with canyons and crenulations. It covers approximately 24 million acres. The plateau rises gradually from about 1,000 feet high on its southern edge to about 2,410 feet in the northcentral area. Uvalde, Real, and Bandera counties are especially rugged, and the land continues to be rugged toward the Rio Grande and the Pecos and Devil's rivers. On the eastern and southern edge of the area lies a prominent geological discontinuity known as the Balcones Fault. Here the 
strata are broken by the uplift of the plateau. Springs flow from the broken strata. Some of these are the Comal Springs at New Braunfels, Goodenough Springs at Comstock, San Marcos Springs at San Marcos, San Felipe Springs at Del Rio, and Barton Springs at Austin. Large springs near San Antonio are the source of the San Antonio River.

A great mass of igneous rocks was thrust up in the northeast corner of the Edwards Plateau, known as the Llano Uplift. It is bordered on the west by Menard County, on the north by San Saba and Mills counties, on the east by Burnet County, and on the south by Gillespie and Blanco counties. This area is famous for its numerous varieties of minerals. Upland soils are of dark calcareous clays and clay loams. Often the soils have an overlay of gravel or stones. Bottomland soils are dark, clayey, and alluvial or sandy. Some deeply cut canyons and stream bottoms contain large boulders and stones rounded from water wear.

Rainfall on the Edwards Plateau decreases from east to west. Boerne averages 32.70 inches annually, Junction 26.29, Ozona 19.50, and from Pecos westward 19.50 or less (see map 2). Rains often come as sudden thunderstorms with force that the sparse vegetation cannot slow and the canyons and arroyos cannot hold. However, in some areas the calcium in the limestone is soluble, and many underground caverns are formed. The colder parts of the area are in the northwest, and the moderate parts toward the southeast.

There are approximately 186 species of trees on the Edwards Plateau, several of which are not found elsewhere. Mesquite, cedar, and a number of oaks are present. Various species of acacia, sumac, buckthorn, and buckeye are found, with willows, cottonwoods, walnuts, and pecans along the streams. Many grass species occur between the patches of shrubs and trees. These open areas sustain cattle, sheep, goats, and numerous deer. The last two also browse the shrubs. In the drier western areas, sotol, yucca, bear grass, and cactus are mixed with the grasses. 


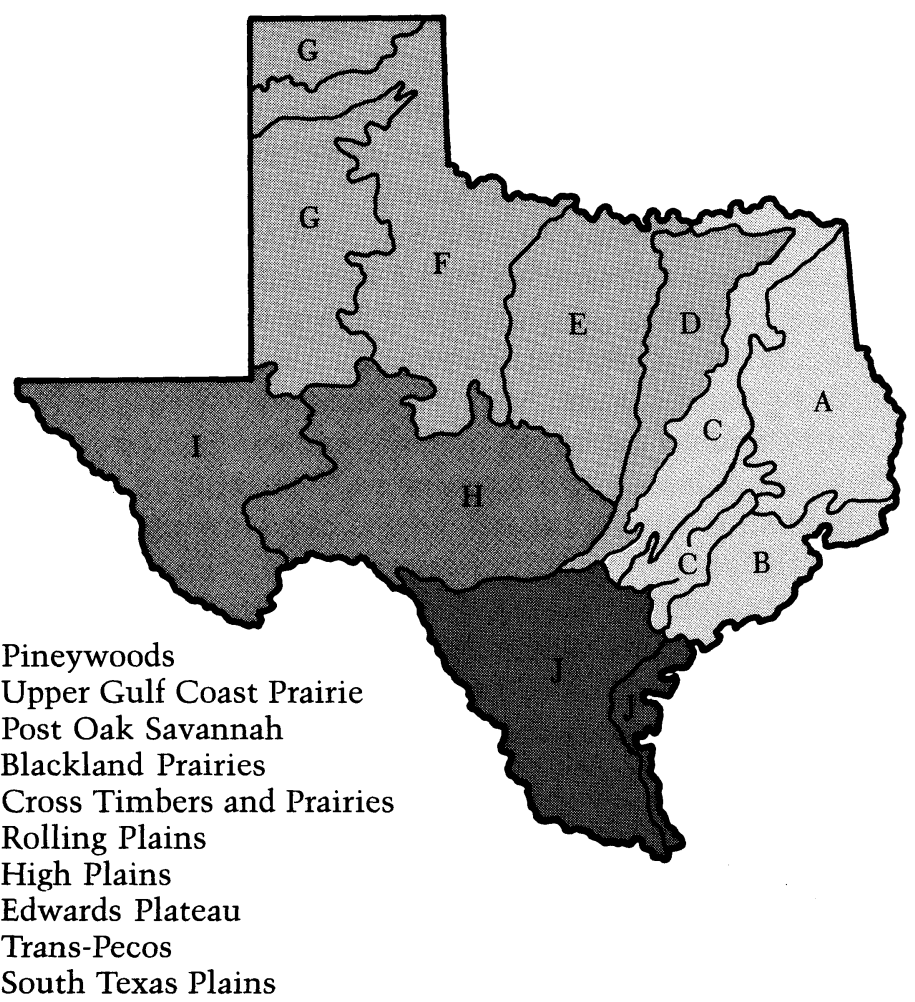

MAP I. Texas tree zones

MAP 2 (opposite). Mean annual temperatures by climatic divisions (I94I-I970) and mean annual precipitation by climatic divisions (I94I-I970) 
INTRODUCTION $\mathrm{xv}$

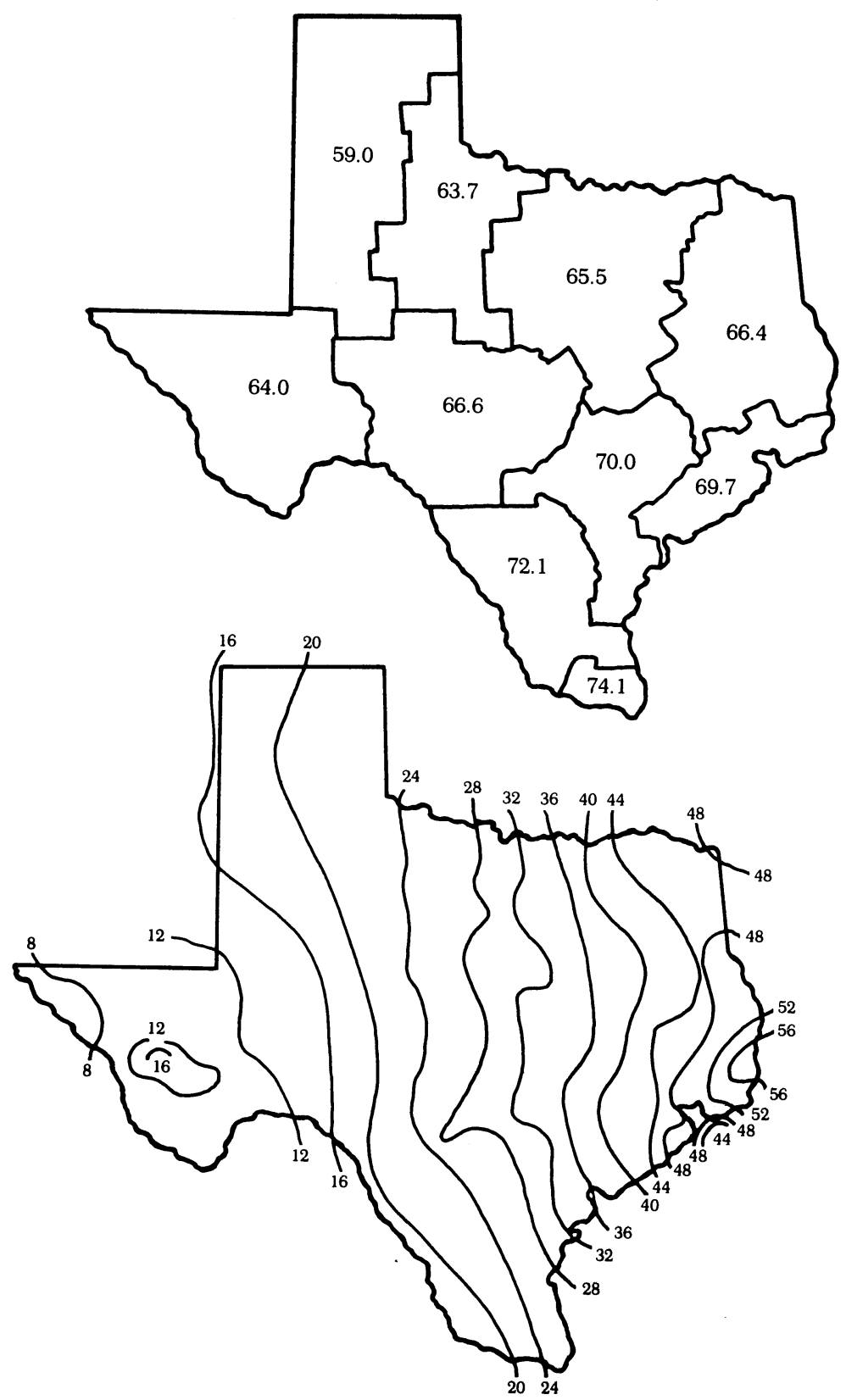


THIS PAGE INTENTIONALLY LEFT BLANK 


\section{TREES OF CENTRAL TEXAS}


THIS PAGE INTENTIONALLY LEFT BLANK 